\title{
An environmental life cycle assessment of forklift operation: a well-to-wheel analysis
}

\author{
Pawel Fuc ${ }^{1} \cdot$ Przemyslaw Kurczewski $^{1}$ - Anna Lewandowska ${ }^{2} \cdot$ Ewa Nowak $^{3}$. \\ Jaroslaw Selech $^{4}$ - Andrzej Ziolkowski ${ }^{1}$
}

Received: 6 June 2015 / Accepted: 26 March 2016 / Published online: 11 April 2016

(C) The Author(s) 2016. This article is published with open access at Springerlink.com

\begin{abstract}
Purpose Among the many publications on the environmental life cycle assessment (LCA) of transport, there are only a few examples of works dedicated to means of internal transport. For this reason, it was decided to gather energy-oriented inventory data and to assess the environmental impact related to the operation of selected forklift trucks, as the most commonly used means of internal transport. This paper presents the main assumptions and the results in relation to the four phases of LCA: the goal and scope definition, the life cycle inventory, the life cycle impact assessment results, and the interpretation. Methods Ten forklifts with different engines were selected in order to carry out the life cycle assessment study. The research was based on the results of measuring the operating fuel consumption and exhaust gas emissions, conducted using the
\end{abstract}

Responsible editor: Wulf-Peter Schmidt

Electronic supplementary material The online version of this article (doi:10.1007/s11367-016-1104-y) contains supplementary material, which is available to authorized users.

Anna Lewandowska

anna.lewandowska@ue.poznan.pl

1 Institute of Combustion Engines and Transport, Poznań University of Technology, Piotrowo av. 3, Poznań 60-965, Poland

2 Department of Commodity Science and Ecology of Industrial Products, Faculty of Commodity Science, Poznań University of Economics, Niepodległości 10, Poznań 61-875, Poland

3 Institute of Chemistry and Technical Electrochemistry, Faculty of Chemical Technology, Poznań University of Technology, Piotrowo 3, Poznań 60-965, Poland

4 Institute of Machines and Motor Vehicles, Faculty of Machines and Transportation, Poznań University of Technology, Piotrowo 3, Poznań 60-965, Poland
SEMTECH-DS mobile device from the PEMS group of devices. In order to make the measurements under a circumstance close to the real conditions of forklift exploitation, it was decided to slightly modify the operating cycle proposed in VDI 2198. The environmental impact of the fuel/electricity usage and exhaust gas emissions was assessed using the ISO 14040x guidelines and the IMPACT 2002+ method.

Results and discussion The study showed that using an electric forklift to transport $1 \mathrm{t}$ of payload over a distance of $1 \mathrm{~km}$ has a significantly smaller environmental impact than using one of the selected forklifts powered by an internal combustion engine. Using forklifts powered by liquefied petroleum gas (LPG) engines leads to a significantly higher environmental impact whilst the use of vehicles with diesel engines has an impact at a level several times lower. In a case of drives without load, where functional unit was defined as covering $1-\mathrm{km}$ distance with no vehicle load, a lower impact for the electric vehicles was also obtained. The analysis includes the influences of the upstream processes of fuel and electrical energy production.

Conclusions Even when Poland's production scenario (based almost entirely on fossil fuels) is taken into consideration, the electric forklifts still show a clear advantage. It should be expected that, if the technological mix of electrical energy production for countries with a higher share of renewable or nuclear energy were to be taken into account, the environmental indicators for electric vehicles would be even lower. It is worth noting that only the energy aspects of forklift operation were analysed. Further studies aiming to collect inventory data relating to other exploitation aspects, as well as the production and utilization of the same vehicles, are planned as a continuation of this research.

Keywords Forklift trucks $\cdot$ LCA $\cdot$ Fuel consumption · Exhaust emissions · Environmental impact · Internal transport 


\section{Introduction}

The implementation of internal transportation processes is an important area of business for many companies (Seidl and Dvo ák 2011), regardless of their size and profile. The economic costs of use of internal transport are a typical component of the companies' accounting (Masztelarz 2010; Michałowska 2013), whereas the environmental consequences associated with it are often overlooked. In many cases, especially in small and medium organizations, there is a lack of awareness of the necessity to pay the environmental fees incurred by the exploitation of internal transport means, which apply particularly to off-road vehicles, such as forklifts, excavators or loaders. To assess the environmental impact of transport processes, one can use the environmental life cycle assessment (LCA), which is a normalized and accepted worldwide environmental management technique, and which includes 'the compilation and evaluation of the inputs, outputs and potential environmental impacts of a product system throughout its life cycle' (ISO 14040 2006; ISO 14044 2006). In this article, the life cycle inventory (LCI) and life cycle impact assessment (LCIA) results are presented for the use of selected forklifts, as the most exploited means of internal transport. The following arguments can be made in support of choosing this topic for research:

- There are many examples of LCA studies regarding various aspects of transport; these aspects include, for example, the life cycles of vehicles or their components (Puri et al. 2009; Amatayakul and Ramnas 2001; Schmidt and Butt 2006; Finkbeiner et al. 2006; Howe et al. 2013), their exploitation (Querini et al. 2011; Koffler and Rohde-Brandenburger 2010; Bartolozzi et al. 2013; Patterson et al. 2013), or matters connected to the use of transport infrastructure (Changa and Kendall 2011; Huang et al. 2009; Yu and Lu 2012; Butta et al. 2012; Du and Karoumi 2012). In most cases, however, they relate to transport outside of the business premises. It was noticed that there are only a few reports on LCA in relation to means of internal transport (Takehisa 2002; Toyota 2003; Jungheinrich 2010).

- Currently, the work of the International Organization for Standardization is being carried out (ISO/TC 207/SC 5life cycle assessment) to develop guidelines for the implementation of LCA for the organizations (ISO/NP TS 14072), and similar work is being undertaken by SETAC/UNEP (Life Cycle Initiative, 2012-2016). Additionally, since the 1st of November 2013, the environmental footprint pilot phase for products and organizations has been initiated. This means that, in the future, LCA will cease to be a technique dedicated only to products and services, as there will also be formal guidelines for the implementation of this kind of approach to the organization itself. Additionally, this means that the possible subjects of LCA studies will also include the various areas of an organization, in which the implementation of internal transport processes can be regarded as an important element.

- A lack of inventory data within LCA databases in relation to the use of forklifts has been identified. The newest version of the ecoinvent database v.3 (Ecoinvent 2013, accessed 2015) only includes inventory information relating to tractors, trailers and loaders, whilst the public ELCD database (prepared by the Institute for Environment and Sustainability, Joint Research Centre) can only provide data for excavators and mining trucks (ELCD 2013, accessed 2015). In the few examples of LCA research on forklifts undertaken by the manufacturers (Jungheinrich 2010), the exhaust gas emissions were not measured, and the calculations were instead made based on conversion factors, i.e. the $\mathrm{CO}_{2}$ conversion factors for each type of fuel. Moreover, in the general LCA databases (Ecoinvent 2013; ELCD 2013), there are inventory data available for the combustion of fossil fuels in the internal combustion engines of passenger cars (fuel consumption, emissions to air, water and soil), which correspond with the engines used in the forklifts selected for analysis. However, these data were calculated for personkilometre, so the unit used is for passenger transport, not goods transport. Additionally, the parameters of the operating engines used in passenger cars vary from the parameters of the engines used in forklifts. As a result, the data are hard to apply to off-road vehicles.

- The functioning emission norms for combustion engines in off-road vehicles (Stage I, Stage II, Stage IIIA, Stage IIIB, Stage IV) (Directive 1997/68/EC; Directive 2002/ 88/EC; Directive 2004/26/EC; Commission Directive 2010/26/EU; Commission Directive 2012/46/EU) provide reference values for the exhaust gas emissions, but these are expressed in units that are hard to apply directly to LCA research $(\mathrm{g} / \mathrm{kWh})$. Moreover, these values are generated from measurements taken in accordance with the guidelines of the ISO 8178 group of standards (ISO 8178-1 2006) - and thus, on the engine test stand, in conditions of static engine exploitation-which do not fully reflect the normal conditions of forklift use.

As there are only a few previous examples of LCA studies conducted on off-road transport, and a lack of relevant information in the databases, steps have been taken to collect inventory data on the energy/fuel consumption and exhaust gas emissions into air of selected forklifts, as well as to determine the resulting impact on the environment. The data were obtained with the use of the latest testing technology for internal combustion engines, i.e. in the real conditions of exploitation, the engines were subject to calculations in units commonly used in LCA studies. 


\section{Methods}

The study used the life cycle assessment (LCA) approach. According to the ISO 14044 requirements (ISO 14044 2006), an LCA study should include the following four phases: goal and scope definition, life cycle inventory, life cycle impact assessment, and interpretation. The life cycle impact assessment (LCIA) calculation was made in the SimaPro 7.1.8 Developer software using the IMPACT $2002+$ method, which itself represents a combination of four different LCIA methods: IMPACT 2002+ (Jolliet et al. 2003), Eco Indicator 99/E (Goedkoop and Spriensma 2000), CML (Guinee et al. 2002) and IPCC (2007).

For the measurement of harmful exhaust gases, the SEMTECH-DS mobile device was used. It belongs to the portable emissions measurement system (PEMS) group of devices, which allowed the concentrations of carbon dioxide $\left(\mathrm{CO}_{2}\right)$, carbon monoxide $(\mathrm{CO})$, nitrogen oxides $\left(\mathrm{NO}_{\mathrm{x}}=\mathrm{NO}+\right.$ $\mathrm{NO}_{2}$ ), total hydrocarbons (THC) and oxygen $\left(\mathrm{O}_{2}\right)$ to be measured (Fig. 1). The measurement of $\mathrm{CO}$ and $\mathrm{CO}_{2}$ was carried out using a non-dispersive infrared (NDIR) analyser, $\mathrm{NO}_{\mathrm{x}}$ was measured with a non-dispersive ultraviolet (NDUV) analyser, THC was measured with a flame ionization detector (FID) and $\mathrm{O}_{2}$ was measured with an electromechanical sensor. The measuring ranges for the analysers were as follows: $\mathrm{CO}_{2}-0$ $20 \%$ (accuracy $\pm 3 \%$ ); $\mathrm{CO}-0-10 \%$ (accuracy $\pm 3 \%$ ); $\mathrm{NO}_{\mathrm{x}}-0-3000 \mathrm{ppm}$ (accuracy $\pm 3 \%$ ); THC $-0-10,000 \mathrm{ppm}$ (accuracy $\pm 2.5 \%$ ); and $\mathrm{O}_{2}-0-20 \%$ (accuracy $\pm 1 \%$ ).

The device was equipped with its own meteorological station, enabling the measurement of pressure, temperature and air humidity. It was also equipped with a global positioning system (GPS) module which allowed to communicate with the vehicle's diagnostic system. The measurement of the mass flow of the exhaust gases was performed using a flowmeter, which operates on the same principle as a Pitot tube.

To assess the energy requirements of forklifts in conditions close to those of actual exploitation, within the framework of the specification VDI 2198 used by the manufacturers, an extra operating cycle was introduced (VDI 2198, 2012). This cycle provided 60 measurements of energy consumption in one hour. VDI 2198 defines the working cycle as a performance of the following tasks: approaching storage bay A with the cargo; lifting the load to a height of $2 \mathrm{~m}$; lowering the

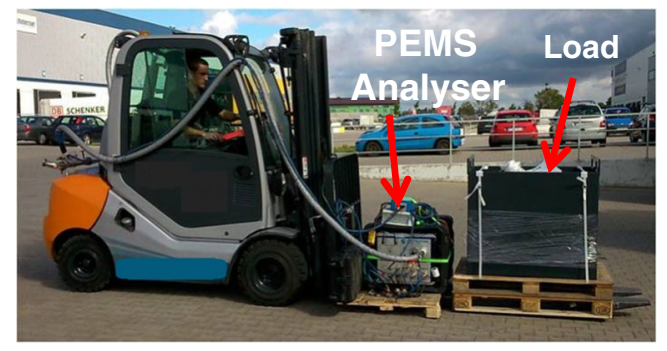

Fig. 1 The installation of the measuring equipment on a forklift truck cargo and backing the forklift out of the bay; approaching storage bay B located at a distance of $30 \mathrm{~m}$ from storage bay $\mathrm{A}$; lifting the load to a height of $2 \mathrm{~m}$; and returning the loaded forklift.

The test outlined in VDI 2198 reflects the conditions of exploitation of forklifts operating in a warehouse: moving between goods storage locations within the storage space (halls, racks etc.) However, intra-warehouse operations are not the only form of forklift usage. They are also employed to unload goods from a vehicle into a warehouse and vice versa. In this situation, the operating cycle of a forklift truck consists of carriage of the payload and so-called empty runs (with no load), and such cycles are common in logistics and warehousing centres (Zychowicz et al. 2008). For this reason, it was decided to slightly modify the operating cycle proposed in VDI 2198 and develop a new operating cycle which would be an even more accurate reflection of the real conditions of forklift exploitation. The developed cycle consists of two phases: (i) transporting the load and (ii) an empty run (Fig. 2). It begins with the driver in the first bay, lifting a load (1) to the height of $1 \mathrm{~m}$ and then lowering the load again. The driver then leaves the bay with the load (2) and drives a distance of $30 \mathrm{~m}$ to the second bay (3). In the second bay, the driver removes the load (4), backs the forklift up (5) and returns to the first bay, following the same route, without the load. This course of action reflects the typical procedure of loading/unloading using the forklift.

All measurements of harmful exhaust gas emissions from the internal combustion engine forklifts were carried out in the open air in front of the warehouses. They were all made within a short period of time (September/October 2014) and in comparable weather conditions. For each analysed forklift, a total of ten measuring cycles (in accordance with the operating cycle shown in Fig. 2) were performed.

\section{Goal and scope definition}

The main objective of the study was to obtain data relating to the energy use of the exploitation of forklifts with different types of engines, based on measurements reflecting the real conditions of use, and to demonstrate these data in a manner appropriate to LCA research. The secondary aim was to determine the environmental impact of different types of forklifts associated with the performance of a functional unit. It was assumed that, considering the role played by forklifts in various transport processes, it would be best to convert the data into tonne-kilometres ( $\mathrm{tkm})$, as a unit of measurement of the transport work carried out by the freight carriers. The tkm unit is used in practice in freight transport and in LCA databases in relation to the carriage of goods (Spielmann et al., 2007). At the same time, this approach is consistent with the most commonly performed engine analyses, whether the 
Fig. 2 The diagram of the working cycle developed for the study

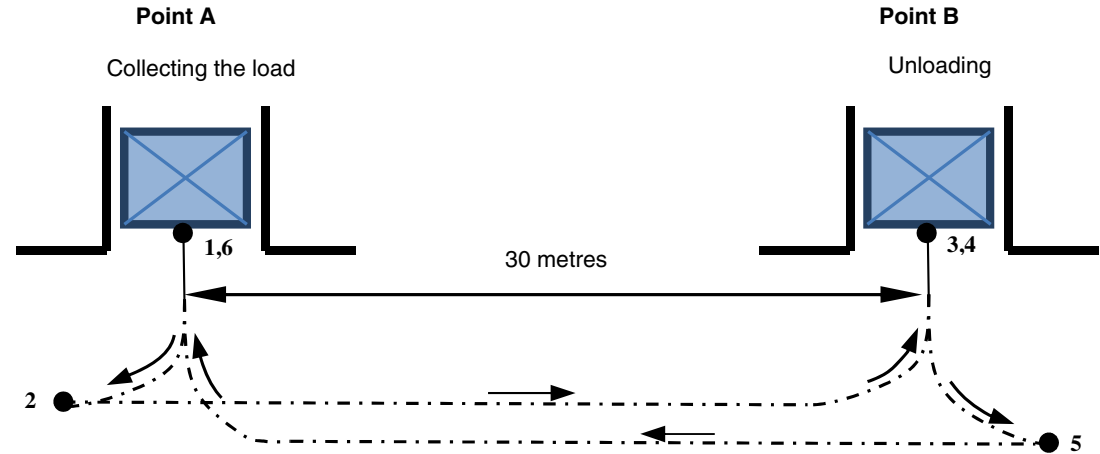

conversion units used are $\mathrm{g} / \mathrm{km}$ (emissions in relation to distance) or $\mathrm{g} / \mathrm{kWh}$ (emissions in relation to power generated by the engine) (Fuc et al. 2013). In the case of the empty runs, the data were related to $\mathrm{km}$. Accordingly, for the carriage of cargo, the functional unit was defined as the 'transport payload of 1 tonne over a distance of $1 \mathrm{~km}$ ', whilst for empty runs the functional unit was ' $1 \mathrm{~km}$ distance with no vehicle load'.

The analysis was made within the scope of 'well - to wheels', which means that included were the processes of production and transport of the fuel ('well - to - tank') and the environmental aspects directly connected to the fuel consumption ('tank - to - wheels'). The data concerning the fuel production and transportation were taken from ecoinvent 2.2 database.

For the analysis, seven forklifts were selected with internal combustion engines (four powered by liquefied petroleum gas (LPG) and three powered by diesel (DSL)) and three with engines powered by electric alternating current (AC), of which the general technical characteristics are presented in the Electronic Supplementary Material (Tables A and B). All the analysed forklifts showed a similar lifting height of $3000 \mathrm{~mm}$ and a 150-mm full free lift. The forklifts selected included vehicles with a 1.6-t capacity (types: LPG2, LPG3, LPG4, ELE2 and ELE3) and vehicles with a 3.0-t capacity (types: LPG1, DSL1, DSL2, DSL3 and ELE1), since vehicles with these parameters were the most widely used in Polish businesses (Widlak List 2013). All the analysed forklifts were brand new vehicles, produced by three leading manufacturers in the global market, whose combined share of the Polish forklift market in 2012 was $40 \%$ for new vehicles and $33.5 \%$ for used vehicles (Widlak List 2013).

\section{Life cycle inventory}

\subsection{Inventory tables}

In the case of the forklifts powered by internal combustion engines (Table 1), the use of oxygen from the air was demonstrated (as an input from nature), as well as fuel consumption (as an input from the technosphere) and emissions of carbon dioxide $\left(\mathrm{CO}_{2}\right)$, carbon monoxide $(\mathrm{CO})$, nitrogen oxides $\left(\mathrm{NO}_{\mathrm{x}}\right)$ and hydrocarbons (THC) (as outputs to nature/emissions into the air). Because the SEMTECH-DS mobile device only allows hydrocarbons to be measured in general (i.e. total hydrocarbons), an average composition of the hydrocarbon emissions was assumed. For LPG engines, this meant the following: aliphatic alkanes (57\%), aliphatic alkenes (15\%), aromatic hydrocarbons (26\%) and acetylenes (2\%) (Merkisz and Kozak 2002), whilst for diesel engines, the composition was assumed as follows: aliphatic alkanes (61\%), aliphatic alkenes $(18.1 \%)$, aromatic hydrocarbons (17.8\%) and acetylenes (3.1\%) (Carey and Cohen 1980; Hammerle et al. 1994).

The first part of Table 1 shows the results of measurements for the part of the course with payload, i.e. per $1 \mathrm{tkm}$ (transporting a payload of $1 \mathrm{t}$ over a distance of $1 \mathrm{~km}$ ), whilst the second part presents the results for the part of the course without a load, i.e. per $1 \mathrm{~km}$ (covering a distance of $1 \mathrm{~km}$ with no load). The values given in Table 2 are the arithmetic mean $\left(x_{\text {mean }}\right)$ of ten measurements for each parameter, obtained using the SEMTECH-DS device.

The only energy inventory component associated with the use of electric forklifts, i.e. electrical energy consumption (as an input from the technosphere), is presented in Table 3. The electricity consumption evaluated basing on the information taken from technical documentation (eg. travel speed with and without load). In case of one electric forklift (ELE2), the same values of the parameters were declared for travel with and without load, so the same electricity usage was assumed (Table 3).

\subsection{Data quality}

In the case of the forklifts powered by internal combustion engines, the data obtained relating to their fuel and air consumption, and exhaust gas emissions can be regarded as being of good quality. The data were acquired with the use of the latest technology for measuring harmful exhaust gas emissions, conducted in the real operating conditions, i.e. in the place and at the time of the analysed transport processes' implementation. Because these measurements were made in ten repeating cycles, it was possible to determine the uncertainty results by calculating the standard deviation $(\sigma x)$ and the classic coefficient of variation $\left(V_{x}=\frac{\sigma_{x}}{x_{\text {mean }}}\right.$ ) (Ignatczyk 
Table 1 Energy-related inventory data for operation of the forklifts fitted with internal combustion engines

\begin{tabular}{|c|c|c|c|c|c|c|c|c|}
\hline \multirow[t]{2}{*}{ Name } & \multirow[t]{2}{*}{ Unit } & \multicolumn{4}{|c|}{ LPG forklifts } & \multicolumn{3}{|c|}{ Diesel forklifts } \\
\hline & & LPG1 & LPG2 & LPG3 & LPG4 & DSL1 & DSL2 & DSL3 \\
\hline \multicolumn{9}{|l|}{ Drive with load $[1 \mathrm{tkm}]$} \\
\hline \multicolumn{9}{|l|}{ Inputs from nature } \\
\hline Oxygen, in air & $\mathrm{g}$ & 98.14 & 226.40 & 170.30 & 199.92 & 256.02 & 225.13 & 159.03 \\
\hline \multicolumn{9}{|l|}{ Inputs from technosphere } \\
\hline LPG & $\mathrm{dm}^{3}$ & 1.85 & 3.72 & 2.53 & 3.39 & - & - & - \\
\hline Diesel oil & $\mathrm{dm}^{3}$ & - & - & - & - & 0.83 & 0.97 & 0.64 \\
\hline \multicolumn{9}{|c|}{ Outputs to nature (emissions to the air) } \\
\hline Carbon dioxide & $\mathrm{g}$ & 2959.57 & 6023.32 & 4036.34 & 5166.63 & 2152.85 & 2556.34 & 1681.15 \\
\hline Carbon monoxide & $\mathrm{g}$ & 27.04 & 38.04 & 20.04 & 181.62 & 15.62 & 3.01 & 3.22 \\
\hline Nitrogen oxides & $\mathrm{g}$ & 19.63 & 42.23 & 56.05 & 56.27 & 19.53 & 32.63 & 8.31 \\
\hline $\begin{array}{l}\text { Total hydrocarbons } \\
\text { Where: }\end{array}$ & $\mathrm{g}$ & 3.06 & 4.03 & 15.73 & 19.96 & 3.05 & 1.35 & 0.90 \\
\hline Aliphatic alkanes & $\mathrm{g}$ & 1.75 & 2.30 & 8.96 & 11.37 & 1.86 & 0.83 & 0.55 \\
\hline Aliphatic alkenes & $\mathrm{g}$ & 0.46 & 0.60 & 2.36 & 2.99 & 0.55 & 0.24 & 0.16 \\
\hline Aromatic hydrocarbons & $\mathrm{g}$ & 0.80 & 1.05 & 4.09 & 5.19 & 0.54 & 0.24 & 0.16 \\
\hline Acetylenes & $\mathrm{g}$ & 0.06 & 0.08 & 0.31 & 0.40 & 0.09 & 0.04 & 0.03 \\
\hline \multicolumn{9}{|l|}{ Drive without load [1 km] } \\
\hline \multicolumn{9}{|l|}{ Inputs from nature } \\
\hline Oxygen, in air & $\mathrm{g}$ & 64.81 & 80.24 & 68.17 & 42.82 & 124.86 & 180.75 & 122.13 \\
\hline \multicolumn{9}{|l|}{ Inputs from technosphere } \\
\hline LPG & $\mathrm{dm}^{3}$ & 1.21 & 1.36 & 1.05 & 0.73 & - & - & - \\
\hline Diesel oil & $\mathrm{dm}^{3}$ & - & - & - & - & 0.40 & 0.81 & 0.51 \\
\hline \multicolumn{9}{|c|}{ Outputs to nature (emissions to the air) } \\
\hline Carbon dioxide & $\mathrm{g}$ & 1935.16 & 2161.19 & 1678.83 & 1104.07 & 1036.92 & 2143.57 & 1352.01 \\
\hline Carbon monoxide & $\mathrm{g}$ & 13.36 & 2.44 & 9.46 & 47.49 & 7.12 & 2.08 & 2.32 \\
\hline Nitrogen oxides & $\mathrm{g}$ & 13.90 & 20.07 & 28.11 & 12.86 & 9.42 & 27.15 & 6.41 \\
\hline $\begin{array}{l}\text { Total hydrocarbons } \\
\text { Where: }\end{array}$ & $\mathrm{g}$ & 1.51 & 2.04 & 6.72 & 3.93 & 1.52 & 1.03 & 0.69 \\
\hline Aliphatic alkanes & $\mathrm{g}$ & 0.86 & 1.16 & 3.83 & 2.24 & 0.93 & 0.63 & 0.42 \\
\hline Aliphatic alkenes & $\mathrm{g}$ & 0.23 & 0.31 & 1.01 & 0.59 & 0.28 & 0.19 & 0.13 \\
\hline Aromatic & $\mathrm{g}$ & 0.39 & 0.53 & 1.75 & 1.02 & 0.27 & 0.18 & 0.12 \\
\hline Acetylenes & $\mathrm{g}$ & 0.03 & 0.04 & 0.13 & 0.08 & 0.05 & 0.03 & 0.02 \\
\hline
\end{tabular}

and Chromińska 2004). In most cases, low coefficients of variation were found (below $35 \%$ ), indicating poor dispersion and suggesting that the arithmetic mean values correctly reflect the studied parameters. Information on the energy consumption of the electric forklifts was obtained through calculations using the values given by the manufacturers in the vehicles' technical specifications. To calculate the environmental impact, inventory data - including resource extraction, processing, and the transportation of fuel, as well as the production of the electrical energy - were taken from the ecoinvent database. In terms of energy production, the data used corresponded to the electrical energy production scenario in Poland.

\section{Life cycle impact assessment}

The life cycle impact assessment (LCIA) calculation was made in the SimaPro 7.1.8 Developer software, using the IMPACT 2002+ method. In this section, the life cycle impact assessment results are presented, expressed as a single score (ecoindicator result) and as weighted impact category indicator results. In both cases, the results will be expressed in millipoints $(\mathrm{mPt})$. During the interpretation of the LCIA results, the following principle is followed: the higher the positive indicator result, the more negative the environmental impact. Negative indicators are interpreted as environmental profit. 
Table 2 The characterised impact category indicators for transporting the load of $1 \mathrm{t}$ on the distance of $1 \mathrm{~km}$ by the selected forklifts with different types of engines [per $1 \mathrm{tkm}$ ]

Drive with load

\begin{tabular}{|c|c|c|c|c|c|c|}
\hline \multirow[t]{2}{*}{ Impact category } & \multirow[t]{2}{*}{ Unit } & \multicolumn{5}{|l|}{ LPG forklifts } \\
\hline & & LPG 1 & LPG 2 & LPG 3 & LPG 4 & LPG average \\
\hline Carcinogens & $\mathrm{kg} \mathrm{C} 2 \mathrm{H} 3 \mathrm{Cl}$ eq & 2.84 & 3.73 & 14.48 & 18.38 & 9.85 \\
\hline Non-carcinogens & $\mathrm{kg} \mathrm{C} 2 \mathrm{H} 3 \mathrm{Cl}$ eq & 0.007 & 0.015 & 0.010 & 0.014 & 0.012 \\
\hline Respiratory inorganics & kg PM2.5 eq & 0.003 & 0.007 & 0.008 & 0.009 & 0.007 \\
\hline Ionizing radiation & Bq C-14 eq & 8.42 & 16.84 & 11.47 & 15.35 & 13.04 \\
\hline Ozone layer depletion & kg CFC-11 eq & 0.0000005 & 0.000001 & 0.000001 & 0.000001 & 0.000001 \\
\hline Respiratory organics & $\mathrm{kg} \mathrm{C} 2 \mathrm{H} 4 \mathrm{eq}$ & 0.003 & 0.004 & 0.011 & 0.014 & 0.008 \\
\hline Aquatic ecotoxicity & kg TEG water & 147.58 & 293.80 & 208.60 & 278.43 & 232.45 \\
\hline Terrestrial ecotoxicity & kg TEG soil & 31.72 & 63.45 & 43.24 & 57.86 & 49.14 \\
\hline Terrestrial acid/nutri & $\mathrm{kg} \mathrm{SO} 2 \mathrm{eq}$ & 0.12 & 0.26 & 0.33 & 0.34 & 0.26 \\
\hline Land occupation & m2org.arable & 0.003 & 0.007 & 0.005 & 0.006 & 0.005 \\
\hline Aquatic acidification & $\mathrm{kg} \mathrm{SO} 2 \mathrm{eq}$ & 0.020 & 0.042 & 0.048 & 0.051 & 0.040 \\
\hline Aquatic eutrophication & kg PO4 P-lim & 0.0004 & 0.0007 & 0.0005 & 0.0006 & 0.0006 \\
\hline Global warming & $\mathrm{kg} \mathrm{CO} 2$ eq & 3.58 & 7.19 & 4.86 & 6.51 & 5.54 \\
\hline Non-renewable energy & MJ primary & 56.90 & 113.80 & 77.54 & 103.76 & 88.14 \\
\hline Mineral extraction & MJ surplus & 0.003 & 0.005 & 0.004 & 0.005 & 0.004 \\
\hline \multicolumn{7}{|l|}{ Diesel forklifts } \\
\hline Impact category & Unit & DSL 1 & DSL 2 & DSL 3 & DSL average & \\
\hline Carcinogens & $\mathrm{kg} \mathrm{C} 2 \mathrm{H} 3 \mathrm{Cl}$ eq & 1.92 & 0.85 & 0.57 & 1.10 & \\
\hline Non-carcinogens & $\mathrm{kg} \mathrm{C} 2 \mathrm{H} 3 \mathrm{Cl}$ eq & 0.005 & 0.005 & 0.004 & 0.005 & \\
\hline Respiratory inorganics & $\mathrm{kg}$ PM2.5 eq & 0.003 & 0.005 & 0.001 & 0.003 & \\
\hline Ionizing radiation & $\mathrm{Bq} \mathrm{C}-14$ eq & 4.32 & 5.09 & 3.37 & 4.26 & \\
\hline Ozone layer depletion & kg CFC-11 eq & 0.0000003 & 0.0000004 & 0.0000002 & 0.0000003 & \\
\hline Respiratory organics & $\mathrm{kg} \mathrm{C} 2 \mathrm{H} 4 \mathrm{eq}$ & 0.002 & 0.001 & 0.001 & 0.002 & \\
\hline Aquatic ecotoxicity & kg TEG water & 95.33 & 111.17 & 73.65 & 93.37 & \\
\hline Terrestrial ecotoxicity & kg TEG soil & 20.44 & 24.05 & 15.93 & 20.14 & \\
\hline Terrestrial acid/nutri & $\mathrm{kg} \mathrm{SO} 2 \mathrm{eq}$ & 0.12 & 0.19 & 0.05 & 0.12 & \\
\hline Land occupation & m2org.arable & 0.002 & 0.003 & 0.002 & 0.002 & \\
\hline Aquatic acidification & $\mathrm{kg} \mathrm{SO} 2 \mathrm{eq}$ & 0.018 & 0.027 & 0.009 & 0.018 & \\
\hline Aquatic eutrophication & kg PO4 P-lim & 0.0002 & 0.0003 & 0.0002 & 0.0002 & \\
\hline Global warming & $\mathrm{kg} \mathrm{CO} 2 \mathrm{eq}$ & 2.49 & 2.93 & 1.93 & 2.45 & \\
\hline Non-renewable energy & MJ primary & 36.93 & 43.45 & 28.79 & 36.39 & \\
\hline Mineral extraction & MJ surplus & 0.0016 & 0.0018 & 0.0012 & 0.0015 & \\
\hline \multicolumn{7}{|l|}{ Forklifts with electric drive } \\
\hline Impact category & Unit & ELE1 & ELE 2 & ELE 3 & ELE average & \\
\hline Carcinogens & $\mathrm{kg} \mathrm{C} 2 \mathrm{H} 3 \mathrm{Cl}$ eq & 0.0020 & 0.0011 & 0.0008 & 0.0013 & \\
\hline Non-carcinogens & $\mathrm{kg} \mathrm{C} 2 \mathrm{H} 3 \mathrm{Cl} \mathrm{eq}$ & 0.0151 & 0.0083 & 0.0059 & 0.0098 & \\
\hline Respiratory inorganics & $\mathrm{kg}$ PM2.5 eq & 0.0006 & 0.0003 & 0.0002 & 0.0004 & \\
\hline Ionizing radiation & $\mathrm{Bq} \mathrm{C}-14$ eq & 1.06 & 0.58 & 0.42 & 0.69 & \\
\hline Ozone layer depletion & kg CFC-11 eq & 0.00000001 & 0.000000003 & 0.000000002 & 0.000000004 & \\
\hline Respiratory organics & $\mathrm{kg} \mathrm{C} 2 \mathrm{H} 4 \mathrm{eq}$ & 0.000029 & 0.000016 & 0.000011 & 0.000019 & \\
\hline Aquatic ecotoxicity & kg TEG water & 22.06 & 12.11 & 8.65 & 14.28 & \\
\hline Terrestrial ecotoxicity & kg TEG soil & 8.08 & 4.44 & 3.17 & 5.23 & \\
\hline Terrestrial acid/nutri & $\mathrm{kg} \mathrm{SO} 2 \mathrm{eq}$ & 0.009 & 0.005 & 0.004 & 0.006 & \\
\hline Land occupation & m2org.arable & 0.0023 & 0.0013 & 0.0009 & 0.0015 & \\
\hline Aquatic acidification & $\mathrm{kg} \mathrm{SO} 2 \mathrm{eq}$ & 0.0039 & 0.0022 & 0.0015 & 0.0025 & \\
\hline
\end{tabular}


Table 2 (continued)

\begin{tabular}{llllll}
\hline Drive with load & & & & \\
\hline Impact category & Unit & \multicolumn{2}{l}{ LPG forklifts } & & \\
\cline { 2 - 6 } & & LPG 1 & LPG 2 & LPG 3 & LPG 4 \\
\hline Aquatic eutrophication & kg PO4 P-lim & 0.000002 & 0.000001 & 0.000001 & 0.000001 \\
Global warming & kg CO2 eq & 0.67 & 0.37 & 0.26 & 0.43 \\
Non-renewable energy & MJ primary & 7.96 & 4.37 & 3.12 & 5.15 \\
Mineral extraction & MJ surplus & 0.0012 & 0.0007 & 0.0005 & 0.0008 \\
\end{tabular}

\subsection{Carriage of payload}

The obtained results show that, under the assumed conditions of the study, the fulfilment of a functional unit using forklifts powered by LPG engines leads to a significantly higher environmental impact $(\mathrm{LPG} 1=2.217 \mathrm{mPt} / \mathrm{km} ; \mathrm{LPG} 2=3.712 \mathrm{mPt} /$ tkm; LPG3 = $7.592 \mathrm{mPt} / \mathrm{tkm}$; LPG $4=9.521 \mathrm{mPt} / \mathrm{tkm}$ ), whilst the use of vehicles with diesel engines has an impact at a level several times lower (DSL $1=1.568 \mathrm{mPt} / \mathrm{tkm}$; DSL2 $=1.417 \mathrm{mPt} / \mathrm{tkm}$; DSL3 $=0.767 \mathrm{mPt} / \mathrm{tkm})$. The lowest values for the ecoindicator were obtained for the vehicles powered by electricity $(\mathrm{ELE} 1=0.187 \mathrm{mPt} / \mathrm{tkm}$; $\mathrm{ELE} 2=0.103 \mathrm{mPt} / \mathrm{tkm}$; ELE3 $=0.073 \mathrm{mPt} / \mathrm{tkm})$. The average scenarios (LPG average, DSL average, ELE average), based on the average inventory data for all the forklifts of a single type, indicate a 4.6 times higher ecoindicator result for the forklifts powered by LPG in comparison to DSL, and almost 48 times higher in comparison to the electricity-powered forklifts (LPG average $=5.758 \mathrm{mPt} / \mathrm{km} ; \mathrm{DSL}$ average $=1.246 \mathrm{mPt} / \mathrm{tkm}$; ELE average $=0.121 \mathrm{mPt} / \mathrm{km})$.

In the results for the forklifts with internal combustion engines, the impacts generated within three emission impact categories dominate: carcinogens (LPG1 = $50.53 \%$; LPG2=39.71 \%; LPG3=75.3\%; LPG 4=76.20\%; DSL1 $=48.23 \%$; DSL2 $=23.80 \%$; DSL3 = 29.34\%), respiratory inorganics $(\mathrm{LPG} 1=14.8 \%$; LPG2 $=18.71 \%$; LPG3 $=10.74 \%$; LPG $4=8.98 \%$; DSL $1=18.7 \%$; DSL2 $=32.89 \%$; DSL3 $=18.48 \%$ ), and global warming $(\mathrm{LPG} 1=16.32 \%$; LPG2 = $19.71 \%$; LPG3 = $6.46 \%$; LPG

Table 3 Energy-related inventory data for operation of the forklifts fitted with electric drive

\begin{tabular}{|c|c|c|c|c|c|c|c|}
\hline \multirow[t]{3}{*}{ Name } & \multirow[t]{3}{*}{ Unit } & \multicolumn{3}{|c|}{ Drive with load [1 tkm] } & \multicolumn{3}{|c|}{ Drive without load [1 km] } \\
\hline & & \multicolumn{6}{|c|}{ Forklifts with electric drive } \\
\hline & & ELE1 & ELE2 & ELE3 & ELE1 & ELE2 & ELE3 \\
\hline \multicolumn{8}{|c|}{ Inputs from technosphere } \\
\hline Electricity & $\mathrm{kWh}$ & 0.51 & 0.28 & 0.20 & 0.49 & 0.28 & 0.19 \\
\hline
\end{tabular}

$4=6.91 \% ;$ DSL $1=16.06 \% ;$ DSL2 = $20.9 \%$; DSL3 $=25.46 \%$ ). The fourth area in which an environmental impact is produced by forklifts with internal combustion engines is the non-renewable energy impact category, for which the average score is $0.58 \mathrm{mPt}$ for LPG average (10.07\%) and $0.239 \mathrm{mPt}$ for DSL average (19.22\%). The weighted impact category indicators for drives with load were presented in the Electronic Supplementary Material (Fig. A).

In the average scenario (Fig. 3) for forklifts powered by LPG engines (LPG average), the impact concerning carcinogens is equal to $3.888 \mathrm{mPt}$, which is equivalent to $67.53 \%$ of the total impact caused by the implementation of a functional unit by the LPG forklifts. In the case of respiratory inorganics, the impact is equal to $0.673 \mathrm{mPt}$ and consists of $11.69 \%$ of the total ecoindicator result, whilst for global warming, it is $0.559 \mathrm{mPt}(9.71 \%)$. In the case of the averaged data for diesel-powered forklifts (DSL average), the impact in terms of carcinogens is equal to $0.435 \mathrm{mPt}$, which gives $34.90 \%$ of the ecoindicator's total value; for respiratory inorganics, the impact is $0.3 \mathrm{mPt}(24.11 \%)$, and for global warming, it is $0.248 \mathrm{mPt}(19.88 \%)$. In the case of forklifts powered by LPG, the indicator results for the three outputrelated impact categories mentioned above amount, on average, to $89 \%$ of the total environmental impact, while for the diesel-powered vehicles, their contribution is $79 \%$.

The results obtained for electric forklifts show a very small contribution in terms of carcinogens (average of $0.43 \%$ ), but the figures for the remaining three categories increase: respiratory inorganics (average of $0.035 \mathrm{mPt}$, which represents $29.18 \%$ of all the impact), global warming (average of $0.044 \mathrm{mPt}$, which represents $36.11 \%$ of the ecoindicator's total value), and non-renewable energy (average of $0.034 \mathrm{mPt}$, which represents $28.04 \%$ of all the impact). The overall picture of the environmental impact is similar for all the selected types of forklift. It shows the predominance of output-related impact categories (in which the environmental mechanism is activated by emissions), especially those relating to the emission of inorganic compounds and greenhouse gases into the air. In addition, for vehicles powered by internal combustion engines, high levels of carcinogenic impact were obtained, which in the case of the electric vehicles had only a 
Fig. 3 Weighted impact category indicator results for the operating fuel consumption and the exhaust gases emission for the averaged data for the LPG, DSL and ELE forklifts-drive with load [mPt/ tkm]

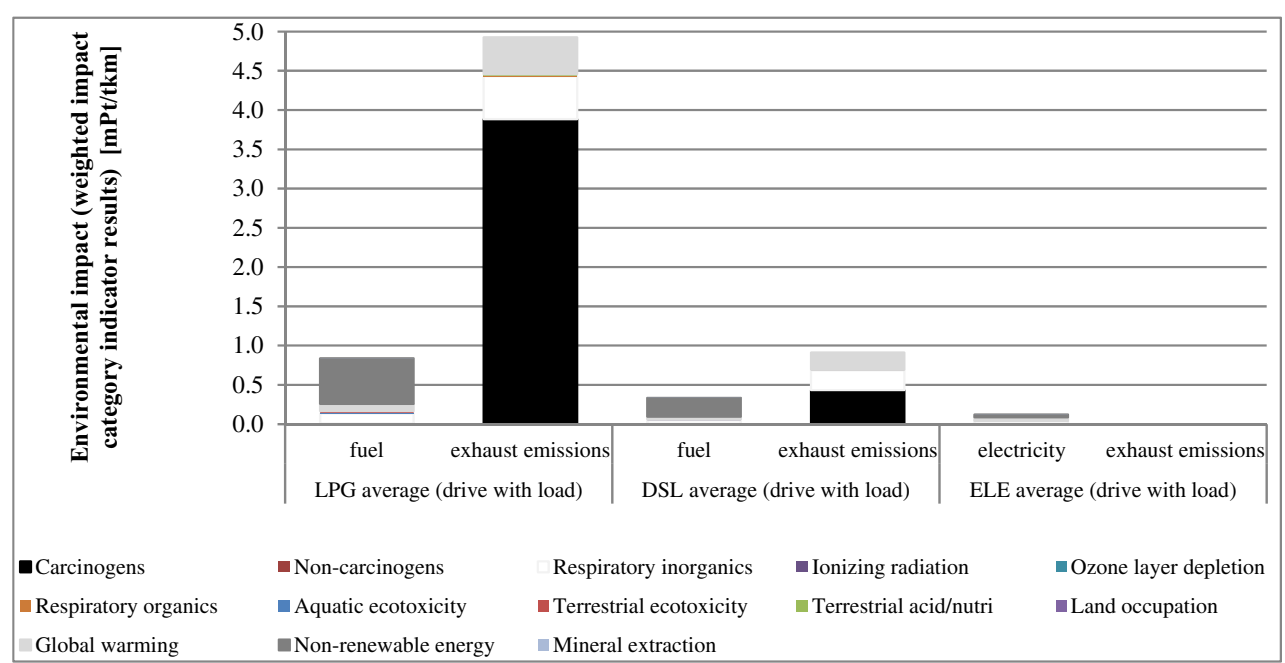

marginal role. The only input-related impact category for which high results were achieved was the exploitation of non-renewable energy sources.

The clear difference in the environmental impact between analysed vehicles can be also observed regarding to the unweighted results. Table 2 presents the characterised impact category indicators for transporting the load of $1 \mathrm{t}$ on the distance of $1 \mathrm{~km}$ by the selected forklifts with different types of engines (please see also Fig. C included in the Electronic Supplementary Material).

\subsection{Empty runs}

Measurements for operating fuel consumption and exhaust gas emissions were also made for journeys made by the selected forklifts with no load. The functional unit was defined in terms of the unloaded vehicle covering a distance of $1 \mathrm{~km}$. The inventory data for these empty runs are presented in Tables 1 and 3, while a summary of the environmental impact is given below (Fig. 4). The overall pictures of impact and vehicle classification are similar, as in the case of journeys made with a load. The performance of electric forklifts leads to a significantly lower environmental impact. The ecoindicator result for the averaged scenario is equal to $0.117 \mathrm{mPt} / \mathrm{km}$ for the electricity-powered forklifts, $0.845 \mathrm{mPt} / \mathrm{km}$ for the forklifts with diesel engines, and $2.024 \mathrm{mPt} / \mathrm{km}$ for the forklifts running on LPG. In a similar manner to the results obtained for the journeys with payload, four main areas of negative environmental impact were identified for the empty runs: carcinogens, respiratory inorganics, global warming and non-renewable energy. The detailed results concerning the environmental impact of drives without load can be found in the Electronic Supplementary Material (Table E-the weighted LCIA results expressed as single score while Table F and Fig. D-the characterised LCIA results for 15 impact categories).

In the case of vehicles with electric engines, the relationship between the values of environmental indicators for
Fig. 4 Weighted impact category indicator results for the operating fuel consumption and the exhaust gases emission for the averaged data for the LPG, DSL and ELE forklifts - drive without load $[\mathrm{mPt} / \mathrm{km}]$

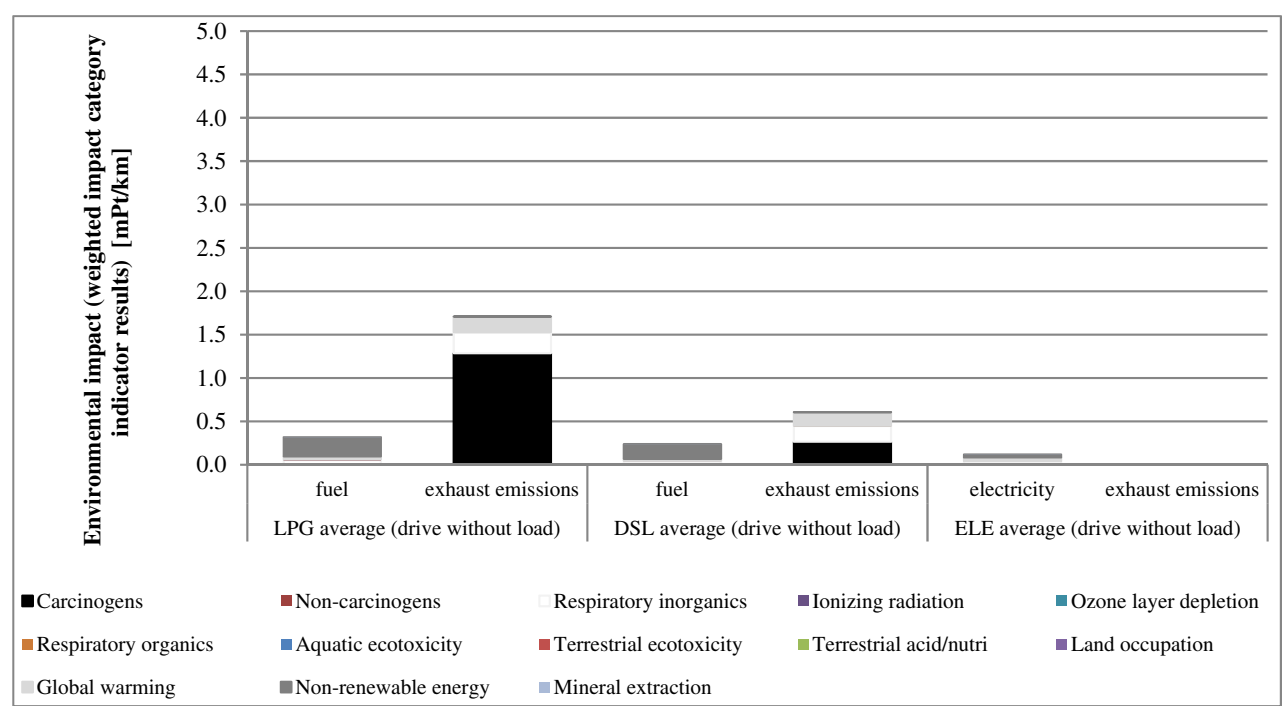


journeys with and without a load corresponds to the difference in electrical energy consumption. Since in the case of the forklift model ELE2, the same energy consumption was assumed for journeys with and without a load, the indicator results for this vehicle are the same and equal to $0.103 \mathrm{mPt} /$ $\mathrm{km}$. For the ELE1 vehicle, electrical energy consumption decreases by $3.92 \%$ for an empty run, when compared to a journey with a load, and the same decrease was obtained for the ecoindicator value $(0.187 \mathrm{mPt} / \mathrm{tkm}$ for a journey with a load and $0.179 \mathrm{mPt} / \mathrm{km}$ for an empty run). For ELE3, this difference was $5 \%(0.073 \mathrm{mPt} / \mathrm{km}$ for a journey with a load and $0.07 \mathrm{mPt} / \mathrm{km}$ for an empty run).

In the case of vehicles with internal combustion engines, the environmental impact is mainly due to the emission of hydrocarbons and carbon dioxide, as exhaust gases generated during the vehicle's operation. For this reason, the differences in the measured emission levels of these compounds, observed between the journeys with and without payload, determined the ecoindicator results. For the empty runs marked as LPG1, LPG2, LPG3 and LPG4, the ecoindicators obtained were $42.57,56.42,56.67$ and $79.79 \%$, respectively, being lower than for the same vehicles' journeys with payload. These values correspond to the differences between measured emissions of carbon dioxide and hydrocarbons for the two types of journey. The situation is similar for the dieselpowered forklifts. In this case, the ecoindicators obtained were lower by $50.86 \%$ (DSL1), $18.47 \%$ (DSL2) and $21.38 \%$ (DSL3). Table 4 includes the unweighted impact category indicators where the difference in the environmental impact of drives without load presented (please see also Fig. D included in the Electronic Supplementary Material).

\subsection{Uncertainty analysis}

Measurements of operating fuel consumption and exhaust gas emissions were made in a series of ten cycles for each forklift truck. On this basis, the uncertainty indicators (standard deviation, coefficient of variation) were determined for each inventory element entered into the SimaPro Developer calculating software. Information on the uncertainty of inventory data related to upstream processes (the excavation and processing of oil, the production and transmission of electrical energy) was taken from the ecoinvent database v. 2.2 and used for the calculations. The uncertainty analysis was made using 1000 Monte Carlo simulations, and the results presented in Table 5 were obtained. The coefficients of variation for the ecoindicator results for electricity-powered vehicles were at a level below $35 \%$, indicating a low dispersion and a good description of the phenomena by the arithmetic mean. In the case of LPG-powered forklifts, higher values for the coefficients of variation were obtained, which could be a result of the higher proportion of exhaust gas emissions involved in generating the overall environmental impact (their measured values for LPG-powered forklifts showed noticeable variations).

\section{Discussion}

It is important to investigate the exhaust gas emissions under conditions closer to those of the actual exploitation of forklifts. Tables 1 and 3 show the energy-related inventory data for the operation of the analysed forklifts. In the case of forklifts powered by internal combustion engines, fuel consumption and oxygen and exhaust gas emissions were measured, while for forklifts with electric engines, only electricity use was considered. In the case of forklifts powered by internal combustion engines, the measurements taken with the PEMS analyser were made for a distance of $30 \mathrm{~m}$; a conversion per $1 \mathrm{~km}$ - assuming a linear relationship — was then performed as a next step. A linear relationship is usually assumed in LCA assessments (Guinee et al. 2002), as well as in relation to transport (Spielmann et al. 2007; Ogden and Anderson 2011; Sundvor 2013). For example, the value of GWP 100 a for $1 \mathrm{tkm}(1 \mathrm{t} \times 1 \mathrm{~km})$ of transport by tractor and trailer is $0.312 \mathrm{~kg} \mathrm{CO} \mathrm{CO}_{2 \mathrm{eq}}$, so the potential impact for $5 \mathrm{tkm}$ $(1 \mathrm{t} \times 5 \mathrm{~km})$ will be five times higher $(0.312 \mathrm{~kg}$ $\mathrm{CO}_{2 \mathrm{eq}} \times 5=1.56 \mathrm{~kg} \mathrm{CO}_{2 \mathrm{eq}}$ ) (ecoinvent data v.2.2; method: IPCC 2007).

For most of the measurements, low coefficients of variation were found; only in individual cases for selected parameters were very high values achieved for the variation coefficient. This can be explained by irregular driving. In each case, the forklifts were used by professional operators. These individuals had different levels of experience and approaches to driving the vehicles. Therefore, it would be right to assume that these differences are the result of the human factor, which makes the outcomes correspond even closer to the real conditions of work. The ability to reflect the real operating conditions and the sensitivity to various aspects of the implementation of the transport process are consistent with the specifications for research using devices from the PEMS group.

In the case of internal combustion engine forklifts, the environmental aspects that have a potentially negative impact on the environment are the use of non-renewable fossil fuels and the emission of air pollutants generated as a result of fuel consumption. The fact that, in Table 1, fuel consumption was introduced as an input from the technosphere means that, when calculating its impact on the environment, all associated technological processes are taken into consideration. In such cases, the use of petrol is related to the mining of the primary energy carrier from the field (cradle), its processing and its transport. The emissions occurring as a result of fuel consumption by the forklift engines fall, from the perspective of LCA, under a different inventory category: so-called elementary flows (ISO 14040 2006), which are defined as outputs to 
Table 4 The characterised impact category indicators for the coverage of 1-km distance by the selected forklifts with no payload with different types of engines [per $1 \mathrm{~km}$ ]

Drive without load (empty)

\begin{tabular}{|c|c|c|c|c|c|c|}
\hline \multirow[t]{2}{*}{ Impact category } & \multirow[t]{2}{*}{ Unit } & \multicolumn{5}{|l|}{ LPG forklifts } \\
\hline & & LPG 1 & LPG 2 & LPG 3 & LPG 4 & LPG average \\
\hline Carcinogens & $\mathrm{kg} \mathrm{C} 2 \mathrm{H} 3 \mathrm{Cl}$ eq & 1.38 & 1.88 & 6.20 & 3.61 & 3.26 \\
\hline Non-carcinogens & $\mathrm{kg} \mathrm{C} 2 \mathrm{H} 3 \mathrm{Cl}$ eq & 0.0048 & 0.0055 & 0.0042 & 0.0029 & 0.0044 \\
\hline Respiratory inorganics & $\mathrm{kg}$ PM2.5 eq & 0.0023 & 0.0032 & 0.0040 & 0.0020 & 0.0029 \\
\hline Ionizing radiation & $\mathrm{Bq} \mathrm{C}-14$ eq & 5.45 & 6.19 & 4.79 & 3.30 & 4.95 \\
\hline Ozone layer depletion & kg CFC-11 eq & 0.0000003 & 0.0000004 & 0.0000003 & 0.0000002 & 0.0000003 \\
\hline Respiratory organics & $\mathrm{kg} \mathrm{C} 2 \mathrm{H} 4 \mathrm{eq}$ & 0.0015 & 0.0019 & 0.0046 & 0.0027 & 0.0027 \\
\hline Aquatic ecotoxicity & kg TEG water & 95.18 & 108.37 & 87.15 & 59.64 & 87.94 \\
\hline Terrestrial ecotoxicity & kg TEG soil & 20.53 & 23.33 & 18.04 & 12.44 & 18.66 \\
\hline Terrestrial acid/nutri & $\mathrm{kg} \mathrm{SO} 2 \mathrm{eq}$ & 0.09 & 0.12 & 0.16 & 0.08 & 0.11 \\
\hline Land occupation & m2org.arable & 0.0022 & 0.0025 & 0.0019 & 0.0013 & 0.0020 \\
\hline Aquatic acidification & $\mathrm{kg} \mathrm{SO} 2 \mathrm{eq}$ & 0.014 & 0.019 & 0.023 & 0.011 & 0.017 \\
\hline Aquatic eutrophication & kg PO4 P-lim & 0.00023 & 0.00026 & 0.00020 & 0.00014 & 0.00021 \\
\hline Global warming & $\mathrm{kg} \mathrm{CO} 2$ eq & 2.33 & 2.62 & 2.02 & 1.41 & 2.10 \\
\hline Non-renewable energy & MJ primary & 36.82 & 41.84 & 32.36 & 22.31 & 33.47 \\
\hline Mineral extraction & MJ surplus & 0.0018 & 0.0020 & 0.0016 & 0.0011 & 0.0016 \\
\hline \multicolumn{7}{|l|}{ Diesel forklifts } \\
\hline Impact category & Unit & DSL 1 & DSL 2 & DSL 3 & DSL average & \\
\hline Carcinogens & $\mathrm{kg} \mathrm{C} 2 \mathrm{H} 3 \mathrm{Cl}$ eq & 0.96 & 0.64 & 0.43 & 0.68 & \\
\hline Non-carcinogens & $\mathrm{kg} \mathrm{C} 2 \mathrm{H} 3 \mathrm{Cl}$ eq & 0.0023 & 0.0046 & 0.0029 & 0.0033 & \\
\hline Respiratory inorganics & kg PM2.5 eq & 0.0014 & 0.0039 & 0.0011 & 0.0022 & \\
\hline Ionizing radiation & $\mathrm{Bq} \mathrm{C}-14$ eq & 2.10 & 4.26 & 2.73 & 3.05 & \\
\hline Ozone layer depletion & kg CFC-11 eq & 0.0000002 & 0.0000003 & 0.0000002 & 0.0000002 & \\
\hline Respiratory organics & $\mathrm{kg} \mathrm{C} 2 \mathrm{H} 4 \mathrm{eq}$ & 0.0011 & 0.0011 & 0.0008 & 0.0010 & \\
\hline Aquatic ecotoxicity & kg TEG water & 46.28 & 93.05 & 59.73 & 66.81 & \\
\hline Terrestrial ecotoxicity & kg TEG soil & 9.92 & 20.14 & 12.93 & 14.43 & \\
\hline Terrestrial acid/nutri & $\mathrm{kg} \mathrm{SO} 2 \mathrm{eq}$ & 0.06 & 0.16 & 0.04 & 0.09 & \\
\hline Land occupation & m2org.arable & 0.0010 & 0.0021 & 0.0014 & 0.0015 & \\
\hline Aquatic acidification & $\mathrm{kg} \mathrm{SO} 2 \mathrm{eq}$ & 0.008 & 0.023 & 0.007 & 0.013 & \\
\hline Aquatic eutrophication & kg PO4 P-lim & 0.00011 & 0.00023 & 0.00015 & 0.00016 & \\
\hline Global warming & $\mathrm{kg} \mathrm{CO} 2 \mathrm{eq}$ & 1.20 & 2.46 & 1.56 & 1.74 & \\
\hline Non-renewable energy & MJ primary & 17.92 & 36.39 & 23.35 & 26.07 & \\
\hline Mineral extraction & MJ surplus & 0.0008 & 0.0015 & 0.0010 & 0.0011 & \\
\hline \multicolumn{7}{|l|}{ Forklifts with electric drive } \\
\hline Impact category & Unit & ELE1 & ELE 2 & ELE 3 & ELE average & \\
\hline Carcinogens & $\mathrm{kg} \mathrm{C} 2 \mathrm{H} 3 \mathrm{Cl}$ eq & 0.0019 & 0.0011 & 0.0007 & 0.0013 & \\
\hline Non-carcinogens & $\mathrm{kg} \mathrm{C} 2 \mathrm{H} 3 \mathrm{Cl} \mathrm{eq}$ & 0.0145 & 0.0083 & 0.0056 & 0.0095 & \\
\hline Respiratory inorganics & $\mathrm{kg}$ PM2.5 eq & 0.0005 & 0.0003 & 0.0002 & 0.0003 & \\
\hline Ionizing radiation & $\mathrm{Bq} \mathrm{C}-14$ eq & 1.02 & 0.58 & 0.40 & 0.67 & \\
\hline Ozone layer depletion & kg CFC-11 eq & 0.000000006 & 0.000000003 & 0.000000002 & 0.000000004 & \\
\hline Respiratory organics & $\mathrm{kg} \mathrm{C} 2 \mathrm{H} 4 \mathrm{eq}$ & 0.0000 & 0.0000 & 0.0000 & 0.0000 & \\
\hline Aquatic ecotoxicity & kg TEG water & 21.20 & 12.11 & 8.22 & 13.84 & \\
\hline Terrestrial ecotoxicity & kg TEG soil & 7.77 & 4.44 & 3.01 & 5.07 & \\
\hline Terrestrial acid/nutri & $\mathrm{kg} \mathrm{SO} 2 \mathrm{eq}$ & 0.01 & 0.01 & 0.003 & 0.01 & \\
\hline Land occupation & m2org.arable & 0.0023 & 0.0013 & 0.0009 & 0.0015 & \\
\hline Aquatic acidification & $\mathrm{kg} \mathrm{SO} 2 \mathrm{eq}$ & 0.004 & 0.002 & 0.001 & 0.002 & \\
\hline
\end{tabular}


Table 4 (continued)

Drive without load (empty)

\begin{tabular}{llllll}
\hline Impact category & Unit & \multicolumn{2}{l}{ LPG forklifts } & & \\
\cline { 3 - 6 } & & LPG 1 & LPG 2 & LPG 3 & LPG 4 \\
\hline Aquatic eutrophication & kg PO4 P-lim & 0.0000019 & 0.0000011 & 0.0000008 & 0.0000013 \\
Global warming & kg CO2 eq & 0.64 & 0.37 & 0.25 & 0.42 \\
Non-renewable energy & MJ primary & 7.65 & 4.37 & 2.96 & 4.99 \\
Mineral extraction & MJ surplus & 0.0012 & 0.0007 & 0.0005 & 0.0008 \\
\hline
\end{tabular}

the environment that are not subject to further processing by man. The harmful components of the exhaust gases are emitted at a small height (removed from the engine by the vehicle's exhaust system); the environmental consequences and human exposure to them occur directly and locally, in the same place and time as the transporting process. The fact that both the fuel consumption and the exhaust gas emission of forklifts with internal combustion engines take place directly on the business premises also brings economic consequences. Because of this, according to the 'polluter pays' rule, and in accordance with EU legislation (Directive 2008/50/EC, Directive 2008/1/ EC, Commission Decision of 18 July 2007) and the Polish Environmental Protection Act (EPLA, 2001), the business owners are obliged to pay a fee for the use of the environment.

Table 3 contains only one energy-related aspect of electric forklift use: the usage of electrical energy. From the point of view of electric forklift users, there is no direct consumption of fossil fuels, and no emission of harmful exhaust gas components takes place directly on the premises. If the analysis were limited to the business only, it would be recognized that the utilization of electric forklift trucks is a more environmentally friendly solution. However, according to the LCA method and the fact that electrical energy consumption is an input from the technosphere, to assess its influence on the environment, it is necessary to take into account the entire technological history of the electrical energy's production: from the primary extraction of the fuel resource from the field (cradle), through its processing, transport and use in fuelling the power station, to the transport of the end energy product through the transmission network. In this instance, despite the fact that the emissions created by the fuel burning are not present on the forklift user's premises, they still have an impact in the fuel life cycle and as a result of the processes performed earlier in the supply chain (upstream processes). Thus, the question arises concerning the significance of environmental aspects that have their origin back in the supply chain: during the extraction of the energy sources and the manufacture of transport fuels or electrical energy. It is therefore a question of the environmental impact of the upstream processes. It can be expected that, even though there are no exhaust gas emissions as a direct result of the use of the electric forklifts, some emissions must result from the burning of fossil fuels in the power station; these emissions should be counted into the ecological baggage of electrical energy. The key issue is therefore the energy production infrastructure in a particular country or with a specific provider, from whom the user obtains the electrical energy. In the case of Poland, where $92 \%$ of electrical energy production is based on coal and lignite (Demand for fuels and energy 2009), the energy sector is responsible for significant, economy-wide emissions into the air, the reduction of which is one of the key goals of the Energy Policy of Poland until 2030 (Energy Policy 2009). It should be expected that, if the technological mix of electrical energy production for countries with a higher share of renewable or nuclear energy were taken into account, the environmental indicators for electric vehicles would be even lower.

The primary source of diesel and LPG is crude oil; the indicator for the non-renewable energy impact category is therefore increased for vehicles powered by diesel and LPG, due to this use of fossil fuels. The analysed LPG-powered forklifts used, on average, $2.87 \mathrm{dm}^{3}$ per $1 \mathrm{tkm}$, which

Table 5 Results of uncertainty analysis, based on 1000 Monte Carlo runs (confidence interval $95 \%$ )

\begin{tabular}{llllll}
\hline Scenario & & Mean $[\mathrm{mPt}]$ & Median [mPt] & Standard deviation [mPt] & Coefficient of variation [\%] \\
\hline Drive with load & LPG average & 5.86 & 5.89 & 3.08 & 52.6 \\
& DSL average & 1.26 & 1.26 & 0.337 & 26.9 \\
Drive without load & ELE average & 0.12 & 0.113 & 0.038 & 31.6 \\
& LPG average empty & 2.01 & 2.03 & 0.851 & 42.3 \\
& DSL average empty & 0.84 & 0.84 & 0.207 & 24.6 \\
\hline
\end{tabular}


corresponds to the extraction of $1.79 \mathrm{~kg}$ of oil and $95.56 \mathrm{dm}^{3}$ of natural gas. In the case of diesel-powered forklifts, the average usage of fuel stood at $0.81 \mathrm{dm}^{3}$ per $1 \mathrm{tkm}$, which corresponds to the extraction of $0.74 \mathrm{~kg}$ of oil and $37.29 \mathrm{dm}^{3}$ of natural gas. For that reason, the non-renewable energy indicator result obtained for the LPG average was more than double that of the DSL average. Producing $0.33 \mathrm{kWh}$ of electrical energy (in accordance with the technological scenario for Poland, in which more than $90 \%$ of power comes from coal and lignite) necessitates the extraction of $153.21 \mathrm{~g}$ of hard coal, $184.18 \mathrm{~g}$ of brown coal, $4.28 \mathrm{dm}^{3}$ of natural gas and $3.48 \mathrm{~g}$ of crude oil. Such extraction, however, generates much less of an impact in terms of non-renewable energy than the use of raw materials for the production of diesel and LPG.

Despite the fact that the use of electric forklifts does not lead to direct emissions from the exhaust system, the emission of inorganic compounds, greenhouse gases and carcinogens still takes place in the technological history of electrical energy. The production (from cradle to gate) of $0.33 \mathrm{kWh}$ of electrical energy leads to the emission into water of $0.115 \mathrm{mg}$ of aromatic hydrocarbons, as well as $29.06 \mu \mathrm{g}$ being emitted into air. Moreover, the upstream processes involved in the production of diesel, LPG and electrical energy are responsible for the emission into air of sulphur oxides, particulates $<2.5 \mu \mathrm{m}$, nitrogen oxides, carbon dioxide and methane. The former elements weigh down the result for respiratory inorganics; the latter, the result for global warming.

\section{Conclusions}

The use of LCA method to assess the environmental impact of the use of forklift trucks has at least two main advantages. The first advantage is the possibility to analyse the use of vehicles from the perspective of the life cycle, thus taking into account the direct and indirect environmental aspects and the resulting potential impacts on the environment. This means that not only are aspects taking place directly during the operation of the forklifts evaluated but so are the environmental interventions (the use of resources, emissions into the air, water and soil) that happen during the earlier stages of the fuel or electrical energy life cycle. The life cycle approach allows to assess the environmental impact of internal transportation from the perspective of the product's functionality. The idea of function and the functional unit, as obligatory elements of each LCA study, gives a common basis for a comparative analysis between internal transportation processes carried out during the life cycle of different products. The second essential advantage is that there is a normalized approach for LCA, included in the ISO 14040x group of standards and commonly used in the transport sector.

This LCA study for selected forklifts with different engines was based on the results of measurements of operating fuel consumption and exhaust gas emissions, made with the use of the SEMTECH-DS mobile device from the PEMS group of devices. Measurements were made within a period of several weeks (September/October 2014), in comparable weather conditions and while maintaining identical operating cycles.

The study showed that using an electric forklift to transport $1 \mathrm{t}$ of payload over a distance of $1 \mathrm{~km}$, before performing an empty run covering the same distance of $1 \mathrm{~km}$, generates a significantly smaller environmental impact than using one of the selected forklifts powered by internal combustion engines. The analysis took into account the influences resulting from the upstream processes of fuel and electrical energy production. Even when the Polish production scenario (based almost entirely on fossil fuels) was taken into account, the use of electric forklifts still showed a clear advantage. However, it should be clearly stated that only the energy aspects of forklift operation have been analysed in this LCA study; therefore, the conclusions regarding the less negative impact of electric forklifts can be only drawn in relation to the energy aspects analysed. The work of collecting inventory data relating to other exploitation aspects (the replacement of fluids and parts, repair and maintenance), as well as the production and utilization of the same vehicles, is planned as a continuation of this research, and will be carried out over the next few years. The authors understand that completing the analysis including the construction data (relating to the vehicles' manufacture), as well as the remaining exploitation information, will probably change the obtained results in the quantitative sense. However, the difference in the sizes of the environmental impact of different forklifts, obtained on the basis of the present study, is so large that it can hardly be expected that the infrastructure data will change the results significantly, in the qualitative sense, leading to changes in overall hierarchy. Such a change would be possible if the analysed vehicles differed considerably in their life span, generally understood material construction or the means of final disposal. From the pre-study that has already been carried out by the authors, it is possible to infer that no drastic differences would be revealed by these matters. To sum up, it can be concluded that the measures taken to collect the inventory data related to the life cycles of forklifts, as the most frequently used means of internal transport, can still be identified as a niche area and are worthy of further continuation.

Acknowledgments The authors wish to thank the logistics portal $\log 4 . \mathrm{pl}$ for their advice and organizational support, and the businesses who agreed to lend us the selected forklifts for the emission measurements.

Open Access This article is distributed under the terms of the Creative Commons Attribution 4.0 International License (http:// creativecommons.org/licenses/by/4.0/), which permits unrestricted use, distribution, and reproduction in any medium, provided you give appropriate credit to the original author(s) and the source, provide a link to the Creative Commons license, and indicate if changes were made. 


\section{References}

Amatayakul W, Ramnas O (2001) Life cycle assessment of a catalytic converter for passenger cars. J Clean Production 9:395-403

Bartolozzi I, Rizzi F, Frey M (2013) Comparison between hydrogen and electric vehicles by life cycle assessment: a case study in Tuscany, Italy. Appl Energ 101:103-111

Butta AA, Mirzadeha I, Tollerb S, Birgisson B (2012) Life cycle assessment framework for asphalt pavements: methods to calculate and allocate energy of binder and additives. Int J Pavement Eng 2012:1-13

Carey P, Cohen J (1980) Comparison of gas phase hydrocarbon emissions from light-duty gasoline vehicles and light-duty vehicles equipped with diesel engine; EPA report EPA/AA/CTAB/PA/80-5

Changa B, Kendall A (2011) Life cycle greenhouse gas assessment of infrastructure construction for California's high-speed rail system. Transp Res Part D-Transport Environ 16:429-434

Commission Directive (2007) Establishing guidelines for the monitoring and reporting of greenhouse gas emissions pursuant to Directive 2003/87/EC of the European Parliament and of the Council (notified under document number C(2007) 3416) http://eur-lex.europa.eu/ LexUriServ/LexUriServ.do?uri=OJ:L:2007:229:0001:0085:EN:PDF access: 4th June 2015

Commission Directive 2010/26/EU of 31 March 2010 amending Directive 97/68/EC of the European Parliament and of the Council on the approximation of the laws of the Member States relating to measures against the emission of gaseous and particulate pollutants from internal combustion engines to be installed in non-road mobile machinery. http://eur-lex.europa.eu/LexUriServ/LexUriServ.do? uri=OJ:L:2010:086:0029:0047:EN:PDF access: 4th June 2015

Commission Directive 2012/46/EU of 6 December 2012 amending Directive 97/68/EC of the European Parliament and of the Council on the approximation of the laws of the Member States relating to measures against the emission of gaseous and particulate pollutants from internal combustion engines to be installed in non-road mobile machinery. http://eur-lex.europa.eu/LexUriServ/LexUriServ.do? uri=OJ:L:2012:353:0080:0127:EN:PDF access: 4th June 2015

Demand for fuels and energy (2009) Projection of demand for fuels and energy until 2030. Appendix 2 to "Energy Policy of Poland until 2030". Polish Ministry of Economy. Warsaw, 10 November 2009. http://www.mg.gov.pl/files/upload/8134/Appendix2.pdf access: 4th June 2015

Directive 2002/88/EC of the European Parliament and of the Council of 9 December 2002 amending Directive 97/68/EC on the approximation of the laws of the Member States relating to measures against the emission of gaseous and particulate pollutants from internal combustion engines to be installed in non-road mobile machinery http://eur-lex.europa.eu/LexUriServ/LexUriServ.do?uri= OJ:L:2003:035:0028:0081:EN:PDF access: 4th June 2015

Directive 2004/26/EC of the European Parliament and the Council of 21 April 2004 amending Directive 97/68/EC on the approximation of the laws of the Member States relating to measures against the emission of gaseous and particulate pollutants from internal combustion engines to be installed in non-road mobile machinery http://eur-lex. europa.eu/LexUriServ/LexUriServ.do?uri=OJ:L:2004:146:0001: 0107:EN:PDF access: 4th June 2015

Directive 2008/1/EC of the European Parliament and the Council of 15 January 2008 concerning integrated pollution prevention and control http://eur-lex.europa.eu/LexUriServ/LexUriServ.do?uri= OJ:L:2008:024:0008:0029:EN:PDF access: 4th June 2015

Directive 2008/50/EC of the European Parliament and the Council of 21 May 2008 on ambient air quality and cleaner air for Europe http:// eurlex.europa.eu/LexUriServ/LexUriServ.do?uri=OJ:L:2008: 152:0001:0044:EN:PDF access: 4th June 2015

Directive 1997/68/EC of the European Parliament and the Council of 16 December 1997 on the approximation of the laws of the Member
States relating to measures against the emission of gaseous and particulate pollutants from internal combustion engines to be installed in non-road mobile machinery http://eur-lex.europa.eu/LexUriServ/ LexUriServ.do?uri=CONSLEG:1997L0068:20130110:EN:PDF access: 4th June 2015

Du G, Karoumi R (2012) Life cycle assessment framework for railway bridges: literature survey and critical issues. Struct Infrastruct Eng 2012:1-18

Ecoinvent (2013) www.ecoinvent.ch access: 5th June 2015

ELCD (2013) http://elcd.jrc.ec.europa.eu/ELCD3/processSearch.xhtml access: 5th June 2015

Energy Policy (2009): Energy Policy of Poland until 2030. Appendix to Resolution no. 202/2009 of the Council of Ministers of 10 November 2009. Polish Ministry of Economy. Warsaw, 10 November 2009. http://www.mg.gov.pl/files/upload/8134/ Polityka\%20energetyczna\%20ost_en.pdf access: 4th June 2015

EPLA (2001) The Environmental Protection Law Act of 27 April 2001 (Journal of Laws of 2001 No. 62, item 627) (in Polish) http:// isap.sejm.gov.pl/DetailsServlet?id $=$ WDU20010620627 access: 4th June 2015

Finkbeiner M, Hoffmann R, Ruhland K, Liebhart D, Stark B (2006) Application of life cycle assessment for the environmental certificate of the Mercedes-Benz S-class. Int J Life Cycle Assess 11(4):240 246

Fuc P, Rymaniak L, Ziolkowski A (2013) The correlation of distribution of PM number emitted under actual conditions of operation by PC and HDV vehicles. Air Pollut XXI 174:207-213

Goedkoop M, Spriensma R (2000) The Eco-indicator 99. A damage oriented method for life cycle assessment. Methodology Report, PreConsultants, The Netherlands

Guinee JB, Gorree M, Heijungs R, Huppes G, Kleijn R, Koning A, Oers L, Sleeswijk AW, Suh S, Udo de Haes HA, Bruijn H, Duin R, Huijbregts MAJ, Lindeijer E, Roorda AAH, van der Ven BL, Weidema BP (2002) Handbook on life cycle assessment: Operational Guide to the ISO standards. Part 1,2,3. Kluwer Academic Publishers, Dordrecht Boston London ISBN 978-1402002-28-1

Hammerle RH, Ketcher DA, Horrocks RW, Lepperhoff G, Hüthwohl G, Lüers B (1994) Emissions from current diesel vehicles; SAE Technical Paper Series 942043

Howe S, Kolios AJ, Brennan FP (2013) Environmental life cycle assessment of commercial passenger jet airlines. Transp Res Part DTransport Environ 19:34-41

Huang Y, Bird R, Bell M (2009) A comparative study of the emissions by road maintenance works and the disrupted traffic using life cycle assessment and micro-simulation. Transp Res Part D-Transport Environ 14:197-204

Ignatczyk W, Chromińska M (2004) Statistics - theory and applications. WSB Publishing House, Poznan. ISBN 83-7205204-2

IPCC (2007) IPCC Climate Change Fourth Assessment Report: Climate Change $2007 \mathrm{http} / / / w w w . i p c c . c h / p d f / a s s e s s m e n t-r e p o r t / a r 4 / w g 1 /$ ar4_wg1_full_report.pdf access: 12th November 2015

ISO 14040 (2006) Environmental management - life cycle assessmentprinciples and framework. CEN, Brussels, p 20

ISO 14044 (2006) Environmental management-life cycle assessmentrequirements and guidelines. CEN, Brussels, p 46

ISO 8178-1 (2006) Reciprocating internal combustion engines - exhaust emission measurement-Part 1: test-bed measurement of gaseous and particulate exhaust emissions. CEN, Brussels, p 124

Jolliet O, Margni M, Charles R, Humbert S, Payet J, Rebitzer G, Rosenbaum R (2003) IMPACT 2002+: a new life cycle impact assessment methodology. Int J Life Cycle Assess 8(6):324-330

Jungheinrich (2010) The Jungheinrich Environmental Commendation: an examination to determine the life cycle assessment of the Jungheinrich industrial truck fleet based on ISO 14040; http:// 
www.jungheinrich.com/fileadmin/Redaktion/Presse/PDF/The Jungheinrich_Environmental_Commendation_1.pdf access: 4th June 2015

Koffler C, Rohde-Brandenburger K (2010) On the calculation of fuel savings through lightweight design in automotive life cycle assessments. Int J Life Cycle Assess 15:128-135

Life Cycle Initiative (2012-2016) http://www.lifecycleinitiative.org/ activities/phase-iii/lca-in-organisations/access: 4th June 2015

Masztelarz M (2010) Methods for accounting of ancillary activities' costs (Metody rozliczania kosztów działalności pomocniczej) [IN] Gabrusewicz W. (ed.) Audyt w systemie kontroli; Conference Proceedings, KIBR, Poznan, Poland 29.11.2010 pp. 131-142 ISBN: 978-83-61287-45-2 http://www.pracownicy.ue.poznan.pl/ masztalerz/rozliczanie.produkcji.pomocniczej.pdf (in Polish) access: 5th November 2015

Merkisz J, Kozak M (2002) Benzene emission from car engines working in urban areas. J KONES Intern Combust Engines 3(4):202-213

Michałowska K (2013) Logistics costs in a company (Znaczenie i sposoby rozliczania kosztów logistycznych); Zeszyty Naukowe Uniwersytetu Szczecińskiego nr 765, „Finanse, Rynki Finansowe, Ubezpieczenia" Wydawnictwo Naukowe Uniwersytetu Szczecińskiego. 61(2):325-334. in Polish

Ogden J, Anderson L (eds) (2011) Sustainable transportation energy pathways. a research summary for decision makers; Institute of Transportation Studies. University of California, California

Patterson T, Esteves S, Dinsdale R, Guwy A, Maddy J (2013) Life cycle assessment of biohydrogen and biomethane production and utilisation as a vehicle fuel. Bioresour Technol 131:235-245

Puri P, Compston P, Pantano V (2009) Life cycle assessment of Australian automotive door skins. Int J Life Cycle Assess 14:420-428

Querini F, Béziat JC, Morel S, Boch V, Rousseaux P (2011) Life cycle assessment of automotive fuels: critical analysis and recommendations on the emissions inventory in the tank to wheels stage. Int J Life Cycle Assess 16:454-464

Schmidt WP, Butt F (2006) Life cycle tools within Ford of Europe's product sustainability index. Case study Ford S-MAX \& Ford galaxy. Int J Life Cycle Assess 11(5):315-322

Seidl M, Dvo ák Z (2011) In-house transport as a part of business logistics. J Eng Manag Compet 1(1/2):1-5

Spielmann M, Bauer C, Dones R, Tuchschmid M (2007) Transport services ecoinvent report no. 14 Swiss Centre for Life Cycle Inventories, Dübendorf

Sundvor CF (2013) Life cycle assessment of road vehicles for private and public transportation; Department of Energy and Process Engineering; Norwegian University of Science and Technology http://www.diva-portal.org/smash/get/diva2:654865/ FULLTEXT01.pdf access: 5th November 2015

Takehisa M (2002) Life cycle assessment of forklift trucks. Toyota Ind Tech Rev 44:11-15

Toyota (2003) Environmental conservation activities http://www.toyotaindustries.com/csr/library/pdf2003/P20-21.pdf access: 4th June 2015

VDI 2198 (2012) Type sheets for industrial trucks; VDI-Gesellschaft Produktion und Logistik (GPL); Verein Deutscher Ingenieure e.V., Düsseldorf 2012

Widlak List (2013) Forklifts in Poland - annual market report prepared by Log4.pl, RANDS Andrzej Szymkiewicz (in Polish) http://log4. pl/wydania/widlak_list_2013/\#/3 access: 5th June 2015

Yu B, Lu Q (2012) Life cycle assessment of pavement: methodology and case study. Transp Res Part D-Transport Environ 17:380-388

Zychowicz W, Bielawska D, Lis K (2008) Production organisation at dispatch-handling timber yard, which additionally manufactures simple wood products. Agr Eng 1(99):433-439 